\title{
EVALUATE THE EFFECT OF YELLOW LUPINE AND FENUGREEK EXTRACTS ON BIOCHEMICAL PARAMETERS ON COTTON LEAF WORM
}

\author{
S. N. Hassab(1), M. M. Abozid(2), S. M. Abd El-Gwad(2), A. A. Ahmed(3) \\ and A. A. El-Shikh(1) \\ (1) Plant Protection Institute, Agriculture Researche Center, Egypt. \\ (2) Agricultural biochemistry department, Faculty of Agriculture, Menoufia University, \\ Egypt. \\ (3) Economic Insectes department, Faculty of Agriculture, Menoufia University, Egypt.
}

Received: Apr. 24, 2019

Accepted: Apr. 30,2019

\begin{abstract}
The Egyptian cotton leaf worm is considered the major pest that causes great damage to cotton plants as well as other vegetable crops in Egypt. Great efforts have been made to control this pest chemically. Insecticides of synthetic origin have been used to manage insect pests for more than 50 years. Due to the continuous use of chemical pesticides against this pest, resistance to the action of pesticides had dramatically evolved.

This study was planned to identify the phenolic compounds in ethanol extracts of fenugreek and yellow lupine, on the other hand, investigate the effect of water and alcoholic extracts of fenugreek and yellow lupine on the biochemical responses of the $4^{\text {th }}$ instar larvae of cotton leaf worm. In our study a recommended pesticide namely chlorpyrifos (dursban) was used as a reference. Our results indicated that seven compounds were detected in two ethanolic extracts; gallic acid $(164.409 \mathrm{mg} / \mathrm{ml})$ was the major component in fenugreek extract, while catechin was $(113.705 \mathrm{mg} / \mathrm{ml})$ the major phenolic compound in yellow lupine extract. All tested extracts showed a significant deterioration in biochemical parameters (GOT, GPT, ALP, ACP activities and total protein levels). The $10 \%$ concentration was the best in both plants extracts, while the ethanolic extract of the fenugreek was the most effective of all the extracts used in the experiment. So, we recommended by using fenugreek and yellow lupine extracts as insecticides to control the cotton leaf worm.
\end{abstract}

Key words: Cotton leafworm - Fenugreek - Yellow lupine - Biochemical response.

\section{INTRODUCTION}

The Egyptian cotton leaf worm, Spodoptera Littoralis (Boisd.) (Lepidoptera: Noctuidae) is an economically important polyphagous pest, that causes considerable destruction to numerous important crops in Egypt (Rawi et al., 2011). Chemical insecticides are the most effective control means for this pest, but this approach has become less attractive due to its side effects; environmental pollution, insect resistance, disturbance in natural balance between pests and their natural enemies and high cost of pesticides (Gamil et al., 2011). The ultimate aim of recent researches focuses on development and evaluation of various alternative control strategies to reduce dependence on synthetic pesticides. Recently, attention has been focused on using natural materials (Badawy and El-Aswad, 2012).

On the other hand, many researchers in the field of insect physiology found that the level of protein and some enzymes activities such as GOT, GPT, $A C P$ and ALP are significantly affected when insects treated with insecticides, 
making the assessment of these biochemical indicators very important in understanding and perception of how the pesticides works (El-Sheakh et al., 1990; Abdel-Hafez et al., 1993; Assar et al., 2012 and Khaled and Farag, 2015).

Plant extracts and essential oils are safe, eco-friendly and more compatible with environmental components compared to synthetic pesticides so they come under "Green pesticides" category. Several studies have shown the strong efficacy of some plant extracts, especially neem and zanzalacht as substitutes for pesticides (Hashem et al., 1999; Schmidt et al., 1998; Rawi et al., 2011 and Yousef and EL-Lakwah, 2014).

Since the plant produces secondary compounds, especially phenolic compounds, to protect it from insects that may attack it during its different stages of development, we have the idea of using plant extracts rich in phenolic compounds to evaluate their potential using to reduce the destructive effect of cotton leaf worm on different crops. This study was planned to identify the phenolic compounds in alcoholic extracts of fenugreek and yellow lupine, on the other hand, investigate the effect of cold water and alcoholic extracts of fenugreek and yellow lupine on the biochemical responses of the 4th instar larvae of cotton leaf worm.

\section{MATERIALS AND METHODS}

Rearing of the tested insect Spodoptera littoralis:

The present study was carried out on the Egyptian cotton leafworm, Spodoptera littoralis (Boisd.) (Lepidoptera: Noctuidae). The original susceptible culture of the cotton leafworm, was obtained from a wellestablished culture, maintained at the department of cotton Leaf worm, Plant Protection Research Institute, Sharkia Branch.

\section{Tested plants}

In the present investigation fenugreek seeds and yellow lupine were selected to test their effects against cotton leafworm. The selected plants selected are obtained from a supermarket in Zagazig, Sharkia, Egypt.

Preparation of fenugreek and yellow lupine extracts

The extraction of seeds of fenugreek and yellow lupine was carried out using distilled water and $95 \%$ ethanol as solvents. Extraction using water and ethanol was carried out according to Abd El-Monem et al., (1995).

The extracted solutions were evaporated by rotary evaporator $\left(50^{\circ} \mathrm{C}\right)$ until completely dryness to obtain the extracts crude, then weighted. The crude of each plant was diluted to the desired concentrations $(10 \%, 5 \%$ and $2.5 \%(w / v)$ of distilled water.

Evaluation of extracts of fenugreek and yellow lupine against the cotton leafworm

This experiment was carried out to investigate the effect of a fenugreek seed and a yellow lupine seed extracts on some biochemical aspects attributes of the cotton leafworm. The tested extracts were as follows: water extract of fenugreek; ethanolic extract of fenugreek; water extract of yellow lupine and ethanolic extract of yellow lupine.

Effect of a fenugreek seed and a yellow lupine seed extracts and the insecticide chlorpyrifos on some biochemical responses of cotton leafworm.

For this experiment, the cotton leafworm larvae and larvae treated with chlorpyrifos and plant extracts were investigated. Chlorpyrifos served as a reference for comparison with plant extract against the cotton leafworm. The values obtained from plant extracts and 
chlorpyrifos were compared to control as a percentage.

Sample preparation involves the use of one replicate with ten larvae for each of (biochemical assays of 3,5 and 7 days) for $4^{\text {th }}$ instar larvae. Untreated larvae were used as control. Larvae were weighed and kept in clean jars. Samples were homogenized in distilled water using a Teflon homogenizer surrounded with a jacket of crushed ice. The homogenates were centrifuged at $\mathbf{5 0 0 0}$ rpm for 10 minutes at $5^{\circ} \mathrm{C}$ according to Wigglesworth (1972). The supernatants were immediately assayed to determine biochemical parameters.

\section{Determination of biochemical parameters.}

Colorimetric determination of total soluble protein (TSP) in total homogenate of larval was carried out as described by (Gornall et al., 1949); glutamic oxaloacetic transminase (GOT) and glutamic pyruvic transaminase (GPT) enzyme's activities were determined calorimetrically according to Reitman and Frankle (1957). The activities of acid phosphatase (ACP) and alkaline phosphatase (ALP) were determined using the method of Powell and Smith (1954).

\section{Identification of phenolic compounds by HPLC:}

Phenolic compounds were identified using HPLC according to BenHammouda et al. (1995). The HPLC system is Agilent 1100 series coupled with Mv-vis detector (G 1315B) and (G 1322 A) DEGASSER sample injection of 5 $\mu \mathrm{l}$ were made from an Agilent $\mathbf{1 1 0 0}$ series. The chromatographic separations were performed in ZORBAX. Eclipse XDB-C18 column $(46 \times 250 \mathrm{~mm}$, particle size $5 \mu \mathrm{m})$. A constant flow rate of $4 \mathrm{~mL}$ min was used with two mobile phases: a- $0.5 \%$ acetic acid in $\mathrm{H}_{2} \mathrm{O}$ at $\mathrm{pH} 2.65$.

b- $0.5 \%$ acetic acid in $99 \%$ acetontrile.

\section{Statistical analysis:}

All the obtained data were statistically analyzed as one way ANOVA to determine the significance of differences between means of the experiments data values according to Little and Hills (1975). To make all possible comparisons between means of different treatments, which proved to be statistically significant, least significant different (L.S.D.) test was done.

\section{RESULTS AND DISCUSSION}

The biochemical responses expressed as total soluble protein (TSP) levels and GOT, GPT, ACP and ALP activities were assessed using the water and ethanolic extracts. These extracts were obtained from seeds of fenugreek and yellow lupine using distilled water and $95 \%$ ethanol as solvents. The biochemical responses to plants extracts were applied on $4^{\text {th }}$ instar larvae of the cotton leafworm. In addition, the recommended insecticide, namely chlorpyrifos was used for treatment of $4^{\text {th }}$ instar larvae of the cotton leafworm. This compound was used as a reference standard at a ratio of $1 / 1024 L_{50}$. These attributes were measured at the intervals of 3,5 and 7 days for $4^{\text {th }}$ instar larvae.

Effect of fenugreek extracts, yellow lupine extracts and chlorpyrifos on TSP levels in $4^{\text {th }}$ instar larvae of the cotton leafworm

Data in Table (1) showed that by increasing the concentrations $(2.5,5$ and $10 \%)$ of water and ethanolic extracts of fenugreek and yellow lupine seeds, levels of total soluble protein (TSP) decreased as compared to the control $(25.97 \pm 0.85 \mathrm{mg} / \mathrm{g})$; while chlorpyrifos recorded $18.08 \pm 0.14 \mathrm{mg} / \mathrm{g}$. 
S. N. Hassab, et al.,

(Table 1): Effect of water and alcoholic extracts of fenugreek seeds, yellow lupine seeds and chlorpyrifos on TSP levels $(\mathrm{mg} / \mathrm{g})$ of the cotton leafworm.

\begin{tabular}{|c|c|c|c|c|c|c|c|c|}
\hline \multirow{3}{*}{ Treatments } & \multirow{2}{*}{\multicolumn{3}{|c|}{$\begin{array}{c}\text { Yellow lupine } \\
\text { Concentration of } \\
\text { extract } \\
(\%)\end{array}$}} & \multirow{2}{*}{\multicolumn{3}{|c|}{$\begin{array}{c}\text { Fenugreek } \\
\text { Concentration of } \\
\text { extract } \\
(\%)\end{array}$}} & \multirow{3}{*}{$\begin{array}{l}\text { Chlorpyrifos } \\
0.97 \text { ppm }\end{array}$} & \multirow{3}{*}{ Control } \\
\hline & & & & & & & & \\
\hline & 2.5 & 5 & 10 & 2.5 & 5 & 10 & & \\
\hline $\begin{array}{l}\text { Water } \\
\text { extract }\end{array}$ & $\begin{array}{l}19.63 \pm \\
0.59^{h}\end{array}$ & $\begin{array}{l}17.12 \pm \\
0.52^{f}\end{array}$ & $\begin{array}{l}14.81 \pm \\
0.09^{d}\end{array}$ & $\begin{array}{l}20.08 \pm \\
0.13^{h}\end{array}$ & $\begin{array}{l}16.13 \pm \\
0.16 e^{e}\end{array}$ & $\begin{array}{l}14.29 \pm \\
0.33^{d}\end{array}$ & \multirow[t]{2}{*}{$18.06 \pm 0.16 \mathrm{~g}$} & \multirow[t]{2}{*}{$\begin{array}{l}25.97 \pm \\
0.85 i\end{array}$} \\
\hline $\begin{array}{l}\text { Alcoholic } \\
\text { extract }\end{array}$ & $\begin{array}{l}18.06 \pm \\
0.06{ }^{9}\end{array}$ & $\begin{array}{l}16.29 \pm \\
0.28 \mathrm{e}\end{array}$ & $\begin{array}{l}11.28 \pm \\
0.22^{b}\end{array}$ & $\begin{array}{l}12.7 \pm \\
0.26^{c}\end{array}$ & $\begin{array}{l}11.88 \pm \\
0.28^{b}\end{array}$ & $\begin{array}{l}10.46 \pm \\
0.39 \text { a }\end{array}$ & & \\
\hline
\end{tabular}

Values represent means \pm S.D obtained from (3), means in the same column followed by the same letters do not differ significantly, and when the means followed by different letters differ significantly at $(p \geq 0.05$

Ethanolic extracts of fenugreek seeds in all tested concentrations $(2.5,5$ and $10 \%)$ recorded the best values compared with all treatments (including control and chlorpyrifos) and $10 \%$ concentration induced the lowest value $(10.46 \pm 39$ $\mathrm{mg} / \mathrm{g}$ ).

The aim of studying protein content in insect because it is the major cell components which play the most important role in all biological processes including reproduction and it is major biochemical component necessary for an organism to develop, grow and perform its vital activities (El-Halafawy et al., 2001). Some reports indicated that plant extracts reduced protein level (Baker et al., 2002). Similarly, our observations about effect of the tested extracts are in concordance with that obtained by Mohamed and Rayas, (1995). Additionally, Ali and Azab (2003) observed reduction in the total protein in $4^{\text {th }}$ instar larvae of the cotton leafworm when treated with extracts of seeds of cotton and sunflower plants. Meanwhile, (TSP) level was found to decrease following treatment of $4^{\text {th }}$ instar larvae with chlorpyrifos. This decline in the level of TSP could suggest mobilization of amino acids to meet energy demands in detoxification of the tested insecticide or could be attributed to the hormonal control. This reduction in the protein content may be due to inhibition of DNA and RNA synthesis (El-barky et al., 2008).

Effect of fenugreek extracts, yellow lupine extracts and chlorpyrifos on GOT and GPT activities in $4^{\text {th }}$ instar larvae of the cotton leafworm

Data in Table ( 2 and 3 ) showed that by increasing the concentrations $(2.5,5$ and $10 \%)$ of water and ethanolic extracts of fenugreek and yellow lupine seeds, the activities of GOT and GPT was decreased as compared to the control $(0.71 \pm 0.01$ and $0.73 \pm 0.03 \mu \mathrm{g} / \mathrm{min} / \mathrm{g}$ body weight, respectively); while chlorpyrifos recorded $0.587 \pm 0.015$ and $0.58 \pm 0.017 \mu \mathrm{g} / \mathrm{min} / \mathrm{g}$ body weight, respectively. Ethanolic extracts of fenugreek seeds in all tested concentrations $(2.5,5$ and $10 \%)$ recorded the best values compared with all treatments (including control and chlorpyrifos) and $10 \%$ concentration induced the lowest value. 
(Table 2): Effect of fenugreek extracts, yellow lupine extracts and chlorpyrifos on GOT activity ( $\mu \mathrm{g} / \mathrm{min} / \mathrm{g}$ body weight) of the cotton leafworm.

\begin{tabular}{|c|c|c|c|c|c|c|c|c|}
\hline \multirow{3}{*}{ Treatments } & \multirow{2}{*}{\multicolumn{3}{|c|}{$\begin{array}{c}\text { Yellow lupine } \\
\begin{array}{c}\text { Concentration of } \\
\text { extract }\end{array}\end{array}$}} & \multirow{2}{*}{\multicolumn{3}{|c|}{$\begin{array}{c}\text { Fenugreek } \\
\begin{array}{c}\text { Concentration of } \\
\text { extract }\end{array}\end{array}$}} & \multirow{3}{*}{$\begin{array}{c}\text { Chlorpyrifos } \\
0.97 \text { ppm }\end{array}$} & \multirow{3}{*}{ Control } \\
\hline & & & & & & & & \\
\hline & $2.5 \%$ & $5 \%$ & $10 \%$ & $2.5 \%$ & $5 \%$ & $10 \%$ & & \\
\hline \multirow{2}{*}{$\begin{array}{l}\text { Water } \\
\text { extract }\end{array}$} & $0.63 \pm$ & $0.606 \pm$ & $0.57 \pm$ & $0.56 \pm$ & $0.49 \pm$ & $0.42 \pm$ & \multirow{4}{*}{$\begin{array}{l}0.587 \pm \\
0.015^{f}\end{array}$} & \multirow{4}{*}{$\begin{array}{c}0.71 \pm \\
0.01^{i}\end{array}$} \\
\hline & $0.013^{h}$ & $0.005^{\mathrm{g}}$ & $0.01^{f}$ & $0.02^{f}$ & $0.008^{d}$ & $0.01^{c}$ & & \\
\hline \multirow{2}{*}{$\begin{array}{l}\text { Alcoholic } \\
\text { extract }\end{array}$} & $0.6 \pm$ & $0.54 \pm$ & $0.51 \pm$ & $0.49 \pm$ & $0.399 \pm$ & $0.24 \pm$ & & \\
\hline & $0.01^{\mathrm{g}}$ & 0.012 & $0.01^{\mathrm{e}}$ & $0.015^{d}$ & $0.008^{b}$ & $0.025^{a}$ & & \\
\hline
\end{tabular}

Values represent means \pm S.D obtained from (3), means in the same column followed by the same letters do not differ significantly, and when the means followed by different letters differ significantly at $(p \geq 0.05)$.

(Table 3): Effect of fenugreek extracts, yellow lupine extracts and chlorpyrifos on GPT activity ( $\mu \mathrm{g} / \mathrm{min} / \mathrm{g}$ body weight) of the cotton leafworm.

\begin{tabular}{|l|c|c|c|c|c|c|c|c|}
\hline \multirow{4}{*}{ Treatments } & \multicolumn{3}{|c|}{ Yellow lupine } & \multicolumn{3}{c|}{$\begin{array}{c}\text { Fenugreek } \\
\text { Concentration of } \\
\text { extract }\end{array}$} & \multicolumn{3}{c|}{$\begin{array}{c}\text { Concentration of } \\
\text { extract }\end{array}$} & \multirow{2}{*}{$0.97 \mathrm{ppm}$} & \\
\cline { 2 - 7 } & $2.5 \%$ & $5 \%$ & $10 \%$ & $2.5 \%$ & $5 \%$ & $10 \%$ & & \\
\hline $\begin{array}{l}\text { Water } \\
\text { extract }\end{array}$ & $0.67 \pm$ & $0.614 \pm$ & $0.576 \pm$ & $0.56 \pm$ & $0.49 \pm$ & $0.42 \pm$ & $0.58 \pm$ & $0.73 \pm$ \\
\hline $\begin{array}{l}\text { Alcoholic } \\
\text { extract }\end{array}$ & $0.01^{\mathrm{i}}$ & $0.004^{\mathrm{h}}$ & $0.006^{\mathrm{g}}$ & $0.015^{\mathrm{g}}$ & $0.016^{\mathrm{d}}$ & $0.012^{\mathrm{b}}$ & $0.017^{\mathrm{g}}$ & $0.01^{\mathrm{j}}$ \\
\hline
\end{tabular}

Values represent means \pm S.D obtained from (3), means in the same column followed by the same letters do not differ significantly, and when the means followed by different letters differ significantly at $(p \geq 0.05)$.

Azmi et al (1998) demonstrated that transaminases (GPT and GOT) that help in the production of energy and serve as a strategic link between the carbohydrates and protein metabolism and are known to be decreased during various physiological and pathological conditions and suggested that this may be attributed to the occurrence of reversible binding between bio- insecticides and enzymatic site of action on the enzyme surface. This is may be due to the fact that the relationships between protein synthesis and transaminase levels were affected by the hormonal control of protein synthesis and neurosecretory hormones which involved in the regulation of transaminase levels (Etebari et al., 2005). 
S. N. Hassab, et al.,

Effect of fenugreek extracts, yellow lupine extracts and chlorpyrifos on ACP and ALP activities in $4^{\text {th }}$ instar larvae of the cotton leafworm

Data obtained in Table (4) represented that three concentrations of the alcoholic extract of fenugreek generally caused decrease in levels of acid phosphatase (ACP) activity as compared to both of the control $(8.07 \pm 0.11 \mu \mathrm{g} / \mathrm{min} /$ body weight) and chlorpyrifos $(7.6 \pm 0.06 \mu \mathrm{g} / \mathrm{min} /$ body weight). It recorded $6.96 \pm 0.06 \mu \mathrm{g} / \mathrm{min} /$ body weight at $2.5 \%$ concentration followed by $5.9 \pm 0.12$ and $3.54 \pm 0.3 \mu \mathrm{g} / \mathrm{min} /$ body weight at concentrations of 5 and $10 \%$, respectively. On the other hand, all concentrations of alcoholic extract of yellow lupine decreased levels of ACP activity as compared to the control. Levels of ACP recorded $6.3 \pm 0.122$, $5.29 \pm 0.17$ and $4.15 \pm 0.09 \mu \mathrm{g} / \mathrm{min} / \mathrm{body}$ weight at concentrations of $2.5,5$ and $10 \%$, respectively.

Data tabulated in Table (5) cleared that three concentrations of alcoholic extract of fenugreek caused decrease in levels of alkaline phosphatase (ALP) activity as compared to the control (3.77士
$0.025 \mu \mathrm{g} / \mathrm{min} / \mathrm{g}$ body weight) and ranged between a minimum of $1.74 \pm 0.15 \mu \mathrm{g} / \mathrm{min} / \mathrm{g}$ body weight at $10 \%$ concentration to a maximum of $2.46 \pm 0.1 \mu \mathrm{g} / \mathrm{min} / \mathrm{g}$ body weight at $2.5 \%$ concentration.; while it recorded $2.62 \pm 0.2 \mu \mathrm{g} / \mathrm{min} / \mathrm{g}$ body weight when larvae were treated with chlorpyrifos. On the other hand, three concentrations of alcoholic extract of yellow lupine caused reduction in levels of ALP activity as compared to the control. It recorded $3.08 \pm 0.02,2.57 \pm 0.08$ and $2.01 \pm 0.026 \mu \mathrm{g} / \mathrm{min} / \mathrm{g}$ body weight at $2.5,5$ and $10 \%$ concentrations.

Ibrahim and Abd El-Kareem (2018) showed that ACP and ALP enzymes were significantly decreased when $4^{\text {th }}$ instar larvae of the cotton leafworm were treated with some plant extracts. Similar observations were mentioned by Mohamed, (2012) who concluded that bioactive compounds isolated from fenugreek seeds include flavonoids which have remarkable biological activities, including inhibitory effects on enzyme.

(Table 4): Effect of fenugreek extracts, yellow lupine extracts and chlorpyrifos on ACP activity $(\mu \mathrm{g} / \mathrm{min} / \mathrm{g}$ body weight) of the cotton leafworm.

\begin{tabular}{|c|c|c|c|c|c|c|c|c|}
\hline \multirow{3}{*}{ Treatments } & \multirow{2}{*}{\multicolumn{3}{|c|}{$\begin{array}{c}\text { Yellow lupine } \\
\begin{array}{c}\text { Concentration of } \\
\text { extract }\end{array}\end{array}$}} & \multirow{2}{*}{\multicolumn{3}{|c|}{$\begin{array}{c}\text { Fenugreek } \\
\begin{array}{c}\text { Concentration of } \\
\text { extract }\end{array}\end{array}$}} & \multirow{3}{*}{$\begin{array}{l}\text { Chlorpyrifos } \\
0.97 \text { ppm }\end{array}$} & \multirow[t]{3}{*}{ Control } \\
\hline & & & & & & & & \\
\hline & $2.5 \%$ & $5 \%$ & $10 \%$ & $2.5 \%$ & $5 \%$ & $10 \%$ & & \\
\hline $\begin{array}{l}\text { Water } \\
\text { extract }\end{array}$ & $\begin{array}{l}7.46 \pm \\
0.07^{e}\end{array}$ & $\begin{array}{l}7.18 \pm \\
0.06^{e}\end{array}$ & $\begin{array}{c}6.85 \pm \\
0.065^{e}\end{array}$ & $\begin{array}{c}7.31 \pm \\
0.09\end{array}$ & $\begin{array}{c}6.77 \pm \\
0.1^{\mathrm{e}}\end{array}$ & $\begin{array}{c}6 \pm \\
0.035^{d}\end{array}$ & \multirow[t]{2}{*}{$\begin{array}{c}7.6 \pm \\
0.06^{\mathrm{e}}\end{array}$} & \multirow[t]{2}{*}{$\begin{array}{c}8.07 \pm \\
0.11^{f}\end{array}$} \\
\hline $\begin{array}{l}\text { Alcoholic } \\
\text { extract }\end{array}$ & $\begin{array}{c}6.3 \pm \\
0.122^{d}\end{array}$ & $\begin{array}{c}5.29 \pm \\
0.17^{c}\end{array}$ & $\begin{array}{l}4.15 \pm \\
0.09^{b}\end{array}$ & $\begin{array}{c}6.96 \pm \\
0.06^{e}\end{array}$ & $\begin{array}{l}5.9 \pm \\
0.12^{d}\end{array}$ & $\begin{array}{c}3.54 \pm \\
0.3^{\mathrm{a}}\end{array}$ & & \\
\hline
\end{tabular}

Values represent means \pm S.D obtained from (3), means in the same column followed by the same letters do not differ significantly, and when the means followed by different letters differ significantly at $(p \geq 0.05)$. 
Evaluate the effect of yellow lupine and fenugreek extracts on

(Table 5): Effect of fenugreek extracts, yellow lupine extracts and chlorpyrifos on ALP activity ( $\mu \mathrm{g} / \mathrm{min} / \mathrm{g}$ body weight) of the cotton leafworm.

\begin{tabular}{|l|c|c|c|c|c|c|c|c|}
\hline \multirow{4}{*}{ Treatments } & \multicolumn{3}{|c|}{ Yellow lupine } & \multicolumn{3}{c|}{ Fenugreek } & Chlorpyrifos & Control \\
\cline { 2 - 7 } & \multicolumn{3}{|c|}{$\begin{array}{c}\text { Concentration of } \\
\text { extract }\end{array}$} & \multicolumn{3}{c|}{$\begin{array}{c}\text { Concentration of } \\
\text { extract }\end{array}$} & \multirow{2}{*}{$0.97 \mathrm{ppm}$} & \\
\cline { 2 - 8 } & $2.5 \%$ & $5 \%$ & $10 \%$ & $2.5 \%$ & $5 \%$ & $10 \%$ & & \\
\hline $\begin{array}{l}\text { Water } \\
\text { extract }\end{array}$ & $3.05 \pm$ & $2.81 \pm$ & $2.56 \pm$ & $2.86 \pm$ & $2.45 \pm$ & $2.15 \pm$ & $2.62 \pm$ & $3.77 \pm$ \\
\hline $\begin{array}{l}\text { Alcoholic } \\
\text { extract }\end{array}$ & $0.05^{\mathrm{e}}$ & $0.046^{\mathrm{d}}$ & $0.056^{\mathrm{c}}$ & $0.064^{\mathrm{d}}$ & $0.13^{\mathrm{c}}$ & $0.081^{\mathrm{b}}$ & $0.2^{\mathrm{c}}$ & $0.025^{\mathrm{f}}$ \\
\hline
\end{tabular}

Values represent means \pm S.D obtained from (3), means in the same column followed by the same letters do not differ significantly, and when the means followed by different letters differ significantly at $(p \geq 0.05)$.

The ALP and ACP activities were found to be low during the larval molting stage and to increase gradually after molting. Higher enzyme activity in the midgut of control insects is most probably due to consumption as well as utilization of large quantities of food. Imbalance in the enzyme-substrate complex and inhibition of peristaltic movement of the gut might have inhibited the enzyme activity in the treated insects (Hori, 1969). Also, enzyme production is clearly related to the feeding behavior (amount of food that passes through the alimentary canal) (Chapman, 1985).

As a matter of fact, changes in ALP and ACP activities after treatment indicated that changing the physiological balance of the mid-gut might affect these enzymes. Apparently, decreased level of ACP suggested reduced phosphorus liberation for energy metabolism, decreased rate of metabolism, as well as decreased rate of transport of metabolites, and may be due to the direct effect of the treatments on enzyme regulation (Shoukry et al., 2003).
HPLC identification of phenolic compounds in alcoholic extracts of fenugreek seeds and yellow lupine seeds:

Among the phenolic compounds of fenugreek seeds extract; gallic acid, syringic acid, cumaricacid, ferulic acid, noringenin, querctin and cinamicacid were detected; while the phenolic compounds of yellow lupine seeds; catechin, syringic acid, vanillin, ferulic acid, noringenin, querctin and cinamic acid were detected (Table 6). Gallic acid was the main phenolic acid which was detected in alcoholic extract of fenugreek seeds; while catechin was the main phenolic acid which was detected in alcoholic extract of yellow lupine (Table 6).

Secondary plant metabolites and their degradation products are important in all agro ecosystems. Phenolic compounds have been intensively studied with regard to their toxicity (Hakim et al., 2010). They play prominent roles in plant herbivore and plant-pathogen interactions (Appel, 1993). 
S. N. Hassab, et al.,

(Table 6): Concentrations of phenolic compounds $(\mathrm{mg} / \mathrm{ml})$ in alcoholic extracts of fenugreek and yellow lupine seeds by using HPLC

\begin{tabular}{|l|c|c|}
\hline Phenolic Compounds & $\begin{array}{c}\text { Fenugreek (mg/ml) } \\
\text { Conc(mg/gm) }\end{array}$ & Yellow lupine (mg/ml) \\
\hline Gallic acid & 169.409 & 113.705 \\
\hline Catechin & ND & ND \\
\hline Caffeic acid & ND & 0.612 \\
\hline Syringic acid & 8.437 & ND \\
\hline Rutin & ND & ND \\
\hline Cumaric acid & 3.255 & 0.744 \\
\hline Vanillin & ND & 0.188 \\
\hline Ferulic acid & 3.032 & 4.354 \\
\hline Noringenin & 2.120 & 2.391 \\
\hline Querctin & 0.458 & 0.455 \\
\hline Cinamic acid & 0.422 & \\
\hline
\end{tabular}

ND: Not detected

\section{Conclusion}

Fenugreek and yellow lupine seeds extracts showed a significant deterioration in biochemical parameters GOT, GPT, ALP, ACP activities and total protein levels) in $4^{\text {th }}$ instar larvae of the cotton leafworm. On the other hand, the $10 \%$ concentration was the best in both plants, while the ethanolic extract of the fenugreek was the most effective of all the extracts used in the experiment. Gallic acid was the major component in fenugreek extract, while catechin was the major phenolic compound in yellow lupine extract. So, we recommended by using fenugreek and yellow lupine extracts as insecticides to control the cotton leaf worm.

\section{REFERENCES}

Abdel- Hafez, M. M., A. Mohanna, A. ElSheakh and M. Farag (1993). Effect of IGR I insecticide mixture on transamines and phosphatase activity of S. littoralis larvae. J. Product and Dev., 1(2): 178- 193.

Abd El- Monem, E., G. A. Kader, M. F. Mitwally and M. A. Taha (1995). Effect of six plant leaf extracts on hatchability of Ostrinia nubilalls (Hubn,) and Spodoptera littoralis eggs in the laboratory. Egyptian $\mathrm{J}$. of Applied Science, 10(3): 304- 312.

Ali, S. H. and A. M. H. Azab (2003). Insecticidal effects of two plant oils emulsion extracts against the cotton 
leafworm, Spodoptera littoralis. Egypt. J. Appl. Sci; 18 (10): 391-399.

Appel, H.M. (1993). Phenolics in ecological interactions: the importance of oxidation. J. of chemical ecology, 19: 1521-1552.

Assar, A.A., M.M. Abo-El- Mahasen, N.M. Harba and A. A. Rady (2012). Biochemical Effects of Cyromazine on Culex pipiens Larvae (Diptera: Culicidae). J Am Sci; 8(5):443-450.

Azmi, M.A., N.H. Sayed and M.F. Khan (1998). Comparative toxicological studies of RB-a (neem Extract) and coopex (Permethrin+Bioallethrin) against Sitophilus oryzae with reference to their effects on oxygen consumption and GOT, GPT Activity. Tur. J. Zoology, 22:307-310.

Badawy, M. E. I. and A. F. EL- Aswad (2012). Insecticidal activity of chitosans of different molecular weights and chitosan-metal complexes against cotton leaf worm (Spodoptera littoralis) and oleander aphid (Aphis nerii). Plant Protect. Sci., 48(3): 131- 141.

Baker, E. R., S. El bermawy, S. Emara, T. Abulzazid and $H$. Abd El-Wahab (2002). Biochemical studies on Spodoptea littoralis developmental stages after larval treatment with different botanial Extracts. $2^{\text {nd }}$ International Conference., plant protect. Res. Inst. Cairo, Egypt, 21 24 Dece. (2): 917 -927.

Ben-Hammouda, M., R.J. Kremer, H. Minor and M.A. Sarwar (1995). Chemical basis of the differential allelopathic potential of Sorghum hybrids on wheat. J.Chem. Ecol. 21:775-786.

Chapman, R. F. (1985). Structure of the digestive systems. In Comprehensive Insect Physiology, Biochemistry and Pharmacology, Vol 4, Ed. Kerkut, G. A. and Gilbert Press, Oxford, UK., 165211.

El-barky, N. M., H. F. Dahi and Y.A. EI Sayed (2008). Toxicological evaluation and biochemical impacts for radient as new generation of spinisyn on $S$. littoralis larvae. Eg. Acad. J. Biolg. Sci.,1(2): 85-97.

El-Halafawy, N. A., T.R. Amin and I. M. Haiba (2001). Biochemical influences of some volatile oils on potato tuber moth, $P$. operculella Zeller (L.: Gelechiidae). Pakistan J. Biol. Sci., 4(8): 983-985.

El-Sheakh, A. A., M. A. Soumaya and A. M. Zeinab (1990). Biological and biochemical changes occurring in Spodoptera littoralis larvae treated with Osbic, Cyanox and Soybean phyloatexins. Egyptian J. of Applied Science, 5(4): 292-302.

Etebari, K., S. Z. Mirhodeini and L. Matindoost (2005). A study on intra specific biodiversity of eight groups of silk worm (Bombyx mori) by biochemical markers. Insect Sci., 12: $87-94$.

Gamil, W. E., F. M. Mariy, L. A. Youssef and S. M. Abdel Halim (2011). Effect of indoxacarb on some biological and biochemical aspects of Spodoptera littoralis. Annl Agric. Sci., 56(2): 121126

Gornall, A. Q., C. J. Bradawill and M.N. David (1949). Determination of proteins by means of biu. reaction. $\mathbf{J}$. Biol. Chem., 177: 751- 766.

Hakim, R.S., K. Baldwin and G. Smagghe (2010). Regulation of midgut growth, development, and metamorphosis. Annual Review of Entomology, 593608.

Hashem, M., S. M. El-Mesiri, F. A. ElMeniawi and I. Rawash (1998). Potency of three plant extracts on the developmental stages of the cotton 
leaf worm. Alex. J. of Agricultural Res., 43(3): 61-79.

Hori, K. (1969). Effect of various activators on the salivary amylase of the bug Lygus disponsi. J. Insect Physiol., (15): 2305-2317.

Ibrahim, S.A. and M.I. Abd El-Kareem (2018). Enzymatic changes and toxic effect of some aromatic plant oils on the cotton leafworm, Spodoptera littoralis. Egypt. Acad. J. Biolog. Sci., 10(1): 13-24.

Khaled, A.S. and S.M. Farag (2015). Toxicological, biological and biochemical impacts of indoxacarb and methoxyfenozoid on the larvae of the cotton leafworm, Spodoptera littoralis (Lepidoptera: Noctuidae). Egypt. Acad. J. Biolog. Sci., 7(1): 2536.

Little, T.M. and F.J. Hills (1975). Statistical methods in agricultural research available from U.C.D. Book, Univ. Calif. Davis. 241276

Mohamed, A.A. and P. Rayas (1995). Composition of Lupinus albus. Cereal Chem. 72(6):643-647.

Mohamed, F.I. (2012). Determination of the genotoxic effect of Trigonella foenumgraecum $L$. extracts in stored Pisum sativum seeds. Asian J. Agricul. Sci., 4(4): 264-269.

Powell, M. A. and I. Smith (1954). The determination of serum acid and alkaline phosphatases activity with 4- amino antipyrine. J. Clin. Pathol., 7: 245- 250.

Rawi, S. M., F. A. Bakry and M. A. AlHazmi (2011). Biochemical and histopathological effect of crude extracts on Spodoptera littoralis larvae. J. Evol. Biol. Res. 3(5): 67-78.

Reitman, S. M. D. and S. Frankel (1957). A colorimetric method for the determination of serum glutamic oxaloacetic acid and glutamic pyruvic transaminase. Ann. J. Clin. Pathol., 28: 56- 62.

Schmidt, G. H., H. Rembold, A. A. I. Ahmed and M. Breuer (1998). Effect of Melia azedarach fruit extract on juvenile hormone titer and protein content in the hemolymph of two species of $N$. lepidopteran larvae (I. Lepidoptera). J. Phytoparasitica., 26(4): 283-292.

Shoukry, I. F., A. A. Khalaf, K.T. Hussein and K. S. Khater (2003). Toxicological evaluation of some botanical oils on biochemical aspects in the Indian meal moth, Plodia interpunctella H. B. (Lepidoptera: Pyralidae). Egypt. J. Biol., 5: 155- 163.

Wigglesworth, V. B. (1972). The principles of insect physiology. 7th Ed. Chapman \& Hall, London, $850 \mathrm{p}$.

Yousef, H. and S. F. El-Lakwah (2014). Effects of Melia azedarach ripe fruit extract on some enzyme activities of the cotton leaf worm Spodoptera littoralis. Egyp. J Biolog. Pest Con., 24(2):315-320. 
تقييم تأثير مستخلصات بذور الترمس والحلبة علي المؤشرات البيوكيميائية لاودة ورق القطن

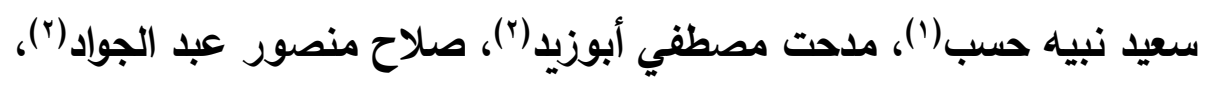

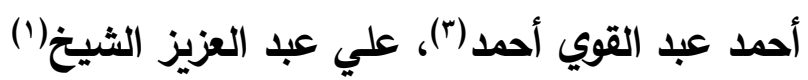
(1) (1) معهز بحوث وقاية النبات - مركز البحوث الزراعية الكمباء

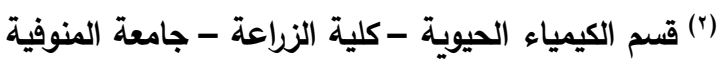

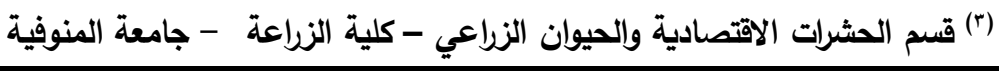
الملخص العربي

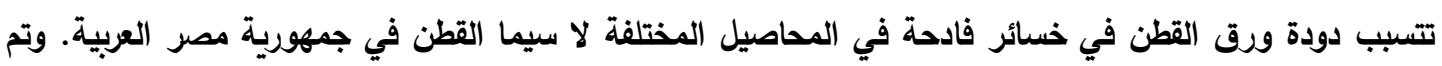

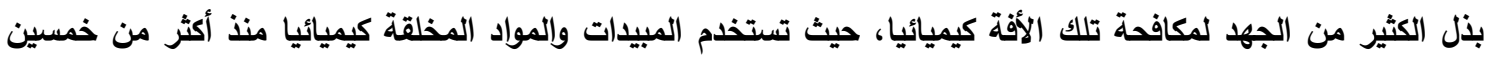

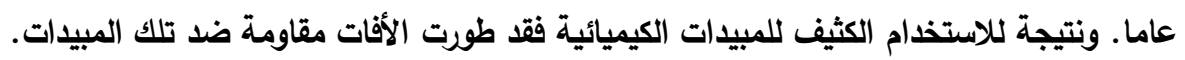

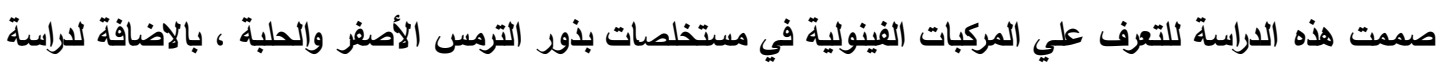

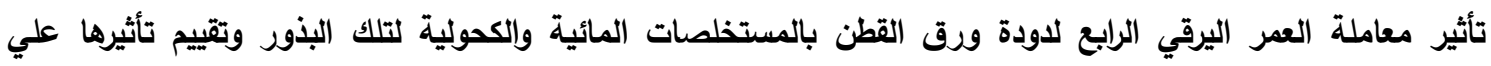
المؤشرات البيوكيميائية.

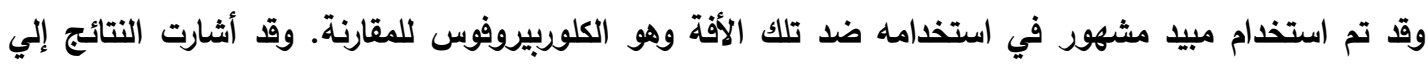

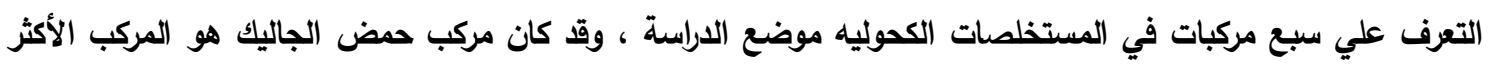

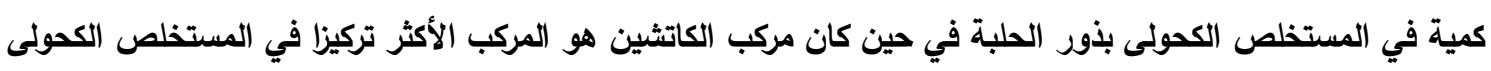

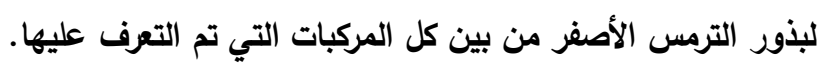

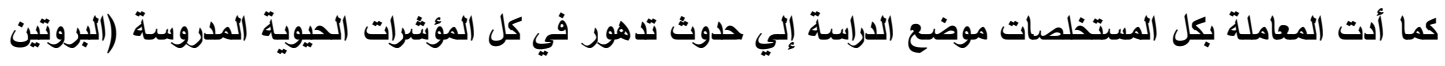

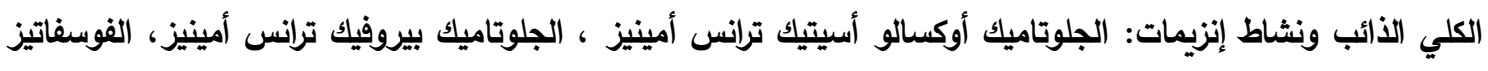

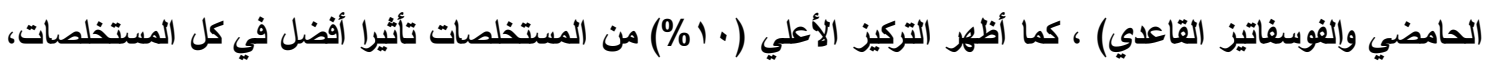

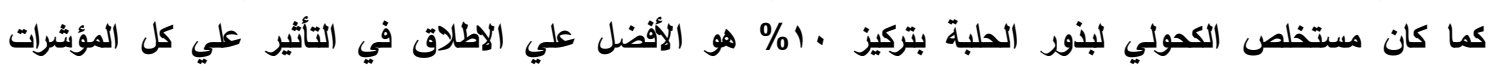

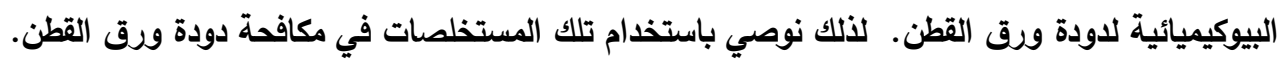
الكلمات الاالة: دودة ورق القطن - الحلبة - الترمس - الاستجابة البيوكيمائية.

\footnotetext{
أسماء السادة المحكمون:

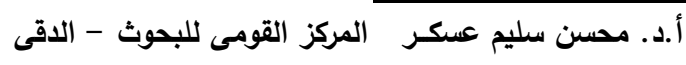

أ.د. يوسف أمين عثوش كلية الزراعة - جامعة المنوفية
} 